\title{
Assessment of the Level of Hazard Analysis and Critical Control Point (HACCP) Prerequisites Adopted in Poultry Meat Production and Processing in Khartoum State, Sudan
}

\author{
Mona Ahmed Babiker Ahmed, Atif Elamin Abdelgadir, and Hayfa Mohammed Ismail
}

\section{ABSTRACT}

This study was conducted to evaluate the current implementation level of Hazard Analysis and Critical Control Point (HACCP) prerequisites adopted in poultry meat production and processing in Khartoum State, Sudan. To achieve the goal, a cross sectional study was conducted. Data and samples were collected from January to September 2018 from 12 close system broiler slaughterhouses according to Non-Probability Multistage Cluster Sampling Method in Khartoum, Khartoum North (Bahri), and Omdurman localities (4 farms from each). A standardized questionnaire was conducted for slaughterhouses (12 for each) to investigate the current status of implemented HACCP prerequisites. One hundred and eighty swab samples were taken from different sites in the slaughterhouses' halls (surfaces, workers' hands, boots, water, and chillers) followed by 240 swab samples collected from broiler carcasses after 4 process steps (defeathering, evisceration, washing and chilling). After bacterial culturing, isolation, and identification, all collected Data were subjected to descriptive and analytical statistic such as Chi square and ANOVA using SPSS. Low level of good practices in slaughterhouses was shown regarding programmed documented personal hygiene staff training and qualification for responsibilities $50.0 \%(n=6)$, preventative maintenance $41.7 \%$ $(n=5)$, and appropriate use of personal facilities $58.3 \%(n=7)$. In addition to that, $66.7 \%(n=8)$ of examined premises showed difficulty in cleaning, inadequate ventilation and $33.3 \% \quad(n=4)$ showed lack of sanitary facilities (dispensers, personnel changing rooms, toilets, washing basins). Unhealthy practices and habits were observed in majority of workers during work such as not washing hands before entering production areas, smoking, and eating and drinking in processing areas, beside low level of medical check in two thirds of them $66.7 \%(n=8)$. Bacterial growth was shown in $60.0 \% \quad(n=108)$ and $58.80 \% \quad(n=141)$ of slaughterhouses' halls samples and meat samples respectively. There was significant difference between state of growth of slaughterhouses' halls sample and farm location $\left(\chi^{2}=7.22\right.$ and $P$-value $\left.=0.027\right)$ while a high significant difference in association between state of growth of meat samples and slaughterhouses' location $\left(\chi^{2}=43.02\right.$ and $P$-value $\left.=0.000\right)$ was revealed. The Gram positive and Gram negative isolates were mostly detected in workers' hands $19.60 \%(n=56)$ and $4.36 \%(n=12)$ respectively. The difference between growth state of bacteria in slaughterhouses' halls samples and sample sites was highly significant $\left(\chi^{2}=30.92\right.$ and $P$-value $\left.=0.000\right)$ and the highest growth was shown in workers' hands. On the other hand, most of Gram positive and Gram negative bacteria in processing steps were detected after defeathering $14.40 \%(n=41)$ and evisceration $2.49 \%(n=7)$ steps. However, there was no significant difference resulting from association of state of bacterial growth of poultry meat samples and different process steps $\left(\chi^{2}=5.14\right.$ and $P$-value=0.162). Slaughterhouses' halls samples and meat samples were found contaminated with harmful pathogenic bacteria such as Salmonella spp. $1.41 \%(\mathrm{n}=4)$, Escherichia coli $9.51 \%$ ( $(\mathrm{n}=27)$, Staphylococcus aureus $7.75 \%(\mathrm{n}=22)$, Citrobacter frundi $1.41 \%$ $(n=4)$, and Micrococcus kristanae $8.75 \%(n=24)$. In conclusion, effective adoption of HACCP PRPs and biosecurity measures in Khartoum State has not been given serious attention beside lack of knowledge, resources, and absence of official authority's role. Absence of proper "Farm to Table" hygiene policy in broiler production negatively affects poultry meat hygiene and consequently threatens public health. Therefore, formulation of suitable procedures and regulations by official authorities for implementing HACCP PRPs and biosecurity measures are needed to ensure poultry meat hygiene from primary stages of production till the end product.

Keywords: Bacterial contaminants, HACCP PRPs, Poultry meat, Slaughterhouses.
Submitted : August 20, 2021

Published : September 13, 2021

ISSN: 2684-1827

DOI: 10.24018 /ejfood.2021.3.5.360

Mona Ahmed Babiker Ahmed *

Department of Preventive Medicine and Veterinary Public Health, Faculty of Veterinary Medicine, University of Khartoum, Sudan.

Atif Elamin Abdelgadir

Faculty of Veterinary Medicine, Faculty of Veterinary Medicine, University of Khartoum, Sudan.

(e-mail: atifvet@yahoo.com)

Hayfa Mohammed Ismail

University of Khartoum, Sudan.

*Corresponding Author 


\section{INTRODUCTION}

Poultry industry is one of the world's fastest growing sectors of meat production [1], [2]. In Sudan, it is also growing rapidly and became important source of food and income [3]. Poultry meat serves as important source of animal protein in Sudan and even in those areas of the world that have protein insufficiency. In 2005, Ministry of Agriculture, Animal Resources and Irrigation reported that most of poultry production in Sudan centered in and around Khartoum State, producing almost $90 \%$ of Sudan's poultry production and it is commercially practiced in open, semi-closed and closedsystem farms.

Across the world, including Sudan, new methods and technologies for transforming poultry production from traditional farming into modern industry attaining higher production are being widely adopted [4]. The total poultry meat production per year in Sudan reached 90 million tons [5]. With the increase of consumer awareness of the nutritive value of poultry products, increase in production and the decline in prices relative to the higher prices of other types of animal proteins, the demand for healthy poultry products is increasing rapidly [6].

Being highly vulnerable to be contaminated [7], [8], many countries have been worried about food-borne diseases from poultry meat origin [9]. Moreover, healthy broilers entering poultry processing plants might get contaminated during different steps of production process [10] either by cross contamination from bird to bird [11] or by dirty workers' hands, facilities, and equipment of slaughterhouse as intermediate sources of poultry meat contamination [12]. Therefore, production process needs an elevated rate of hygiene to exclude disease causing agents to safeguard public health [8].

Disease prevention is the most viable and economically feasible approach to control and protect poultry production [13]. Codex Alimentarius Commission (CAC) comprehensively describes basic principles of food hygiene and also provides recommended codes of practice for safe food production which includes the globally recognized recommendation for the set-up and implementation of Hazard Analysis and Critical Control Points (HACCP) systems [14]. HACCP system is considered as an initiative step to ensure continuous production of safe poultry meat and it should be implemented and enhanced with the adoption of Good Hygiene Practices (GHPs), Good Manufacturing Practices (GMPs) [14], [15] as prerequisites.

Unfortunately, poultry production in Sudan was identified mostly to have inadequate health care, inappropriate housing, poor knowledge of poultry management, and unsafe poultry meat production processing [16]. Many studies revealed high level of microbiological contamination due to the absence of implementation of different food safety systems prerequisites in processing plants [17]. Ahmed [18] assessed the measures of poultry meat safety in one of the slaughterhouses in Khartoum, Sudan based on of HACCP system PRPS adopted. She indicated that Escherichia coli, Staphylococcus spp. and Salmonella spp. were isolated from the samples examined. Another study also revealed high microbial level of pathogenic bacteria on poultry carcasses which reflected poor hygienic management concluding that it is far away from international standards [5], [19].

Elniema et al. [20] and Doménech et al. [21] stated that HACCP is a worldwide accepted and effective food safety assurance system that can be applied throughout the food chain from primary production to final product. Youssif [22] reported that the main problem appeared from his study in Khartoum State is that most of the risk factors and shortfalls are associated with the HACCP PRPs since they are the base line of HACCP applications. As a result, the need for development of a disease-free poultry management through the improvement of poultry health concerns is of paramount importance to insure healthy poultry meat production for consumers. The current study aimed mainly to:evaluate the level of Hazard Analysis and Critical Control Point (HACCP) prerequisites adopted in poultry meat production and processing in Khartoum State, Sudan.

\section{MATERIALS AND METHODS}

\section{A. Study Site}

The current study was carried out in Khartoum State which is located at the central part of Sudan. Khartoum is a tripartite metropolis including three large localities: Khartoum, Bahri (Khartoum North), and Omdurman around which most of the poultry production in Sudan is centered and is estimated as $90 \%$ of Sudan's poultry production [23].

\section{B. Type of Poultry Production Systems in the Study Site}

There are two poultry production systems in Khartoum State, traditional type which is practiced by individual households for domestic consumption in open system and commercial type which is practiced in the closed and semi closed systems. The current study targeted closed system broiler farms and their slaughterhouses in the three localities in Khartoum State: Khartoum, Bahri (Khartoum North), and Omdurman.

\section{Study Design}

Cross sectional study was used mainly to assess the level of Hazard Analysis and Critical Control Point (HACCP) Prerequisites adopted in poultry meat production and processing in Khartoum State, Sudan.

\section{Sampling Method and Sample Size}

Sampling was done with different levels from January to September 2018. Hence, Non-Probability Multistage Sampling Method was used according to support of the owners as described by Thrusfield [24]. Twelve closed system broiler farms' slaughterhouses were included on voluntary basis (4 farms from each locality).

\section{E. Data Collection}

This study was mainly based on qualitative, semistructured questionnaire which was constructed to assess the current status of implementing HACCP PRPs and requirements in the slaughterhouses of the responding farms including GMPs, GHPs and poultry meat product refrigeration and freezing. The questionnaires were pretested in four farms and accordingly wordings and concepts in the questionnaires were amended. Moreover, a total number of twelve manure samples from the broiler houses were 
collected to evaluate the bacterial load (one sample from each chosen house in each farm) and 420 swab samples were taken from slaughterhouses' halls and broiler carcasses for laboratory analysis.

\section{F. Samples Collection}

\section{1) Collection of Slaughterhouses' Swab Samples}

A total of 420 swab samples were collected from slaughterhouses of all respondent farms. One hundred and eighty swab samples were taken from workers' hands, boots, surfaces, fridges, and water used for washing (15 samples for each slaughterhouse). Moreover, 240 swab samples were taken from broiler carcasses after four process steps (PSs) which were defeathering, evisceration, spray wash, and chilling (20 samples for each slaughterhouse). The collected swabs were marked and packed in a cool box $\left(4^{\circ} \mathrm{C}\right)$ and taken immediately to the laboratory to be tested.

\section{2) Data Collection Using Questionnaire}

This study was partially based on a qualitative, semistructured questionnaire. The questionnaire included two parts. The first part was constructed to assess the current status of HACCP strategy PRPs implemented in respondent slaughterhouses including GMPs, GHPs and poultry meat product refrigeration and freezing. The second part was constructed to assess knowledge, attitude, and awareness of personnel about HACCP systems. Pretesting of questionnaire was done in six broiler farms' slaughterhouses. Moreover, general inspection was performed to allow a comparison of the answers given by the farmer and the present situation in the farm.

\section{G. Primary Isolation, Sub-culturing, and Identification of Bacterial Isolates}

Each collected sample which was inoculated into nutrient broth and incubated overnight at $37^{\circ} \mathrm{C}$ then sub cultured onto a blood agar and a Mac Conkey's agar. The inoculated plates incubated for 24-48 h at $37{ }^{\circ} \mathrm{C}$. Purification of culture was done by subculturing part of a typical well separated colony on the corresponding medium. The process was repeated several times. The purity of the culture was checked by examining stained smears. The pure culture was then stored at $4{ }^{\circ} \mathrm{C}$. Smears were made from each type of colony. Then fixed by heating and stained by Gram stain method according to [25]. All biochemical tests that were applied

\section{H. Data Analysis and Management}

Statistical Package for Social Sciences (SPSS) version 19 for windows was used for data analysis [26]. Descriptive statistics such as frequency, mean, percentage, standard deviation, standard error and $95 \%$ confidence interval were used for variables. Analytical statistic was also used, e.g., Chi-square $\left(\chi^{2}\right)$ was used for association between state of growth of bacteria and sample site and different process steps of poultry meat production in the slaughterhouses. All Statistical significance results were set at P-value of $<0.05$. All results were presented in tables and graphs.

\section{RESUlts}

\section{A. Slaughterhouse' Questionnaire Survey Results}

1) Estimation of Workers Knowledge and Awareness about HACCP

Regarding awareness and assessment of knowledge level among workers and personnel in charge, $83.3 \%(n=10)$ of respondent farms stated that they know about HACCP systems. However, the percentage of correct answers about the details of HACCP plan and prerequisites was $41.7 \%$ $(n=5)$. Furthermore, high percentage $83.3 \% \quad(n=10)$ of workers and incharge personnel were willing to learn more about HACCP prerequisites and how to establish HACCP plan (Table I).

TABLE I: ESTIMATION OF WORKERS HACCP KNOWLEDGE IN BROILER

\begin{tabular}{lc}
\multicolumn{1}{c}{ POULTRY FARMS } \\
\hline \multicolumn{1}{c}{ Parameter } & Frequency\% \\
\hline Knowledge about HACCP & $10(83.3 \%)$ \\
1. Yes & $2(16.7 \%)$ \\
2. No & $0(00.0 \%)$ \\
3. I don't know & \\
HACCP is hazards' preventive plan & $8(66.7 \%)$ \\
1. Yes & $1(08.3 \%)$ \\
2. No & $3(25.0 \%)$ \\
3. I don't know & \\
HACCP prerequisites plan Knowledge & $5(41.7 \%)$ \\
1. Yes & $2(16.7 \%)$ \\
2. No & $5(41.7 \%)$ \\
3. I don't know & \\
Workers need for more HACCP information & $10(83.3 \%)$ \\
1. Yes & $0(00.0 \%)$ \\
2. No & $2(16.7 \%)$ \\
3. I don't know
\end{tabular}

*The total number of respondent farms was twelve.

\section{B. GMPs Regarding Personnel, Premises, and Equipment}

Implementing of documented staff training program, training of appropriate wearing of protective clothing and presence of written task or job descriptions for all production personnel scored $33.3 \%(n=4)$. Both giving the staff basic hygiene training and placement of emphasis on washing hands after contamination were implemented in eight slaughterhouses scoring $66.7 \%$. Staff appropriate training and qualification for responsibilities and appropriate use of personal facilities were $50.0 \% \quad(n=6)$ and $58.3 \% \quad(n=7)$, respectively (Table II).

The current results revealed that $75 \%(n=9)$ of the examined slaughterhouses can easily be cleaned and sanitized and also ensure appropriate product and personnel flow. Moreover, half of the examined slaughterhouses (50\%) showed no production line crisscross, and the premise location does not pose a risk of contaminating the product. Similarly, clear separation between clean and dirty areas was only proved in $41.7 \%(n=5)$ of examined slaughterhouses. Preventative maintenance program was only implemented by $41.7 \% \quad(n=5)$ of total respondent slaughterhouses and maintenance tools storage was found in 11 out of $12(91.7 \%)$. Moreover, examination of premises environment revealed that $83.3 \%$ of these slaughterhouses had waterproof floors and water directed to graded, trapped drains. Walls that are durable and impermeable with light-colored washable coating were found in $91.7 \%(n=11)$. Structure materials of slaughterhouses buildings and surrounds design which are 
rot-proof, odorless with clean and easily cleaned ceiling were found in $50 \%$. In addition to that, $75.0 \%(n=9)$ were provided with adequate lighting which does not distort the product colors. About $66.7 \%(n=8)$ of slaughterhouses examined revealed no adequate ventilation and no good steam extraction. Adequate equipment design standards to safeguard the product and equipment calibration records for $\mathrm{pH}$ meters and thermometers were found in $83.3 \% \quad(n=10)$, while equipment calibration procedures were implemented in $75.0 \%(n=9)$ of slaughterhouses (Table II).

TABLE II: GOOD MANUFACTURING PRACTICES (GMPS) REGARDING PERSONNEL, PREMISES AND EQUIPMENTS IN BROILER POULTRY

\begin{tabular}{|c|c|c|}
\hline \multicolumn{3}{|c|}{ SLAUGHTERHOUSES } \\
\hline \multirow{2}{*}{ Parameter } & Yes & No \\
\hline & \multicolumn{2}{|c|}{ Frequency $\%$} \\
\hline \multicolumn{3}{|l|}{ Personnel } \\
\hline \multicolumn{3}{|l|}{ Staff training and task description } \\
\hline Responsibilities qualification & $6(50.0 \%)$ & $6(50.0 \%)$ \\
\hline Documented training program & $4(33.3 \%)$ & $8(66.7 \%)$ \\
\hline Basic training for all staff & $8(66.7 \%)$ & $4(33.3 \%)$ \\
\hline Emphasis on hands hygiene & $8(66.7 \%)$ & $4(33.3 \%)$ \\
\hline Facilities usage training & $7(58.3 \%)$ & $5(41.7 \%)$ \\
\hline Trained for protective wearing & $4(33.3 \%)$ & $8(66.7 \%)$ \\
\hline Written task descriptions & $4(33.3 \%)$ & $8(66.7 \%)$ \\
\hline \multicolumn{3}{|l|}{ Premises } \\
\hline \multicolumn{3}{|c|}{ Location, structure of buildings and surrounds design } \\
\hline $\begin{array}{l}\text { Location posing no risk of } \\
\text { contamination }\end{array}$ & $6(50.0 \%)$ & $6(50.0 \%)$ \\
\hline Easy cleaning and sanitation & $9(75.0 \%)$ & $3(25.0 \%)$ \\
\hline $\begin{array}{l}\text { Ensure easy product and personnel } \\
\text { flow }\end{array}$ & $9(75.0 \%)$ & $3(25.0 \%)$ \\
\hline Separate clean and dirty areas & $5(41.7 \%)$ & $7(58.3 \%)$ \\
\hline No production line criss-cross & $6(50.0 \%)$ & $6(50.0 \%)$ \\
\hline \multicolumn{3}{|l|}{ Maintenance } \\
\hline Preventative maintenance programs & $5(41.7 \%)$ & $7(58.3 \%)$ \\
\hline Maintenance tools storage & $11(91.7 \%)$ & $1(08.3 \%)$ \\
\hline Waterproof flooring & $10(83.3 \%)$ & $2(16.7 \%)$ \\
\hline $\begin{array}{l}\text { Durable, washable light-colored } \\
\text { Walls }\end{array}$ & $11(91.7 \%)$ & $1(08.3 \%)$ \\
\hline $\begin{array}{l}\text { Water directed to graded trapped } \\
\text { drains }\end{array}$ & $10(83.3 \%)$ & $2(16.7 \%)$ \\
\hline Rot-proof and odorless materials & $6(50.0 \%)$ & $6(50.0 \%)$ \\
\hline $\begin{array}{l}\text { Adequate ventilation and steam } \\
\text { extraction }\end{array}$ & $4(33.3 \%)$ & $8(66.7 \%)$ \\
\hline Adequate clear lighting & $9(75.0 \%)$ & $3(25.0 \%)$ \\
\hline Clean and easily cleaned ceiling & $6(50.0 \%)$ & $6(50.0 \%)$ \\
\hline \multicolumn{3}{|l|}{ Equipment Maintenance and } \\
\hline \multicolumn{3}{|l|}{ Calibration } \\
\hline Adequate safe design standards & $10(83.3 \%)$ & $2(16.7 \%)$ \\
\hline Preventative maintenance program & $5(41.7 \%)$ & $7(58.3 \%)$ \\
\hline Maintenance tools storage & $11(91.7 \%)$ & $1(08.3 \%)$ \\
\hline Equipment calibration procedures & $9(75.0 \%)$ & $3(25.0 \%)$ \\
\hline $\mathrm{pH}$ meters and temperature records & $10(83.3 \%)$ & $2(16.7 \%)$ \\
\hline
\end{tabular}

$*$ The total number of respondent slaughterhouses was twelve.

\section{GMPs Regarding Services}

Draining system for condensed water in chillers and adequate supply of electricity were provided in all respondent slaughterhouses and $91.7 \%(n=11)$ were prepared with extra electric power supply for emergency cut and also adequate supply of refrigeration. Implemented pests and rodents control programs were observed in 11 (91.7\%) of the examined slaughterhouses. Moreover, adequate cold and hot water supply with ideal inlet and outlets, were provided in 91.7\% $(n=11)$ and $100 \%(n=12)$ respectively. On the other hand, adequacy of sanitary facilities including dispensers for used disposable items and personnel changing rooms recorded $33.3 \%(n=4)$ and it was only $16.7 \% \quad(n=2)$ for stocked sanitary toilet facilities. The rest of the results are detailed in Table III.

TABLE III: GoOd MANUfACTURING PRACTICES (GMPS) REGARDING SERVICES IN BROILER POULTRY SLAUGHTERHOUSES

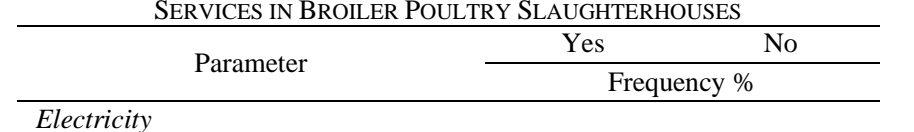

\section{Adequate supply}

$12(100 \%) \quad 0(00.0 \%)$

Reserve for power cuts $11(91.7 \%) \quad 1(08.3 \%)$

Refrigeration

Adequate refrigeration

Water and condensation drainage

Water

Adequate hot and cold water

Top-bottom inlet and outlet

Hygiene and sanitary facilities

Adequate hands and tools facilities

Adequate facilities at wash basin

Adequate foot dips

Adequate disposable dispensers

Adequate toilet facilities

Adequate changing rooms

Drainage and waste disposal

Suitable floor drainage

Water is directed to grated drains

Drains trapped in and outside the

building

Separate toilets drainage lines

Available garbage and waste bins

Wastewater channeled into drains

Adequate facilities for bird wastes removal

$11(91.7 \%) \quad 1(08.3 \%)$

$12(100 \%) \quad 0(00.0 \%)$

Insects and rodents control

Pest and rodent implemented control

program

External openings insect control

devices

Regular emptying of catch trays

Buildings sealed against rodents

$11(91.7 \%) \quad 1(08.3 \%)$

$12(100 \%) \quad 0(00.0 \%)$

$8(66.7 \%) \quad 4(33.3 \%)$

$5(41.7 \%) \quad 7(58.3 \%)$

$7(58.3 \%) \quad 5(41.7 \%)$

$4(33.3 \%) \quad 8(66.7 \%)$

$2(16.7 \%) \quad 10(83.3 \%)$

$4(33.3 \%) \quad 8(66.7 \%)$

$11(91.7 \%) \quad 1(08.3 \%)$

$6(50.0 \%) \quad 6(50.0 \%)$

$6(50.0 \%) \quad 6(50.0 \%)$

$9(75.0 \%) \quad 3(25.0 \%)$

$6(50.0 \%) \quad 6(50.0 \%)$

$11(91.7 \%) \quad 1(08.3 \%)$

$8(66.7 \%) \quad 4(33.3 \%)$

*The total number of respondent slaughterhouses was twelve.

$11(91.7 \%) \quad 1(08.3 \%)$

$10(83.3 \%) \quad 2(16.7 \%)$

$7(58.3 \%) \quad 5(41.7 \%)$

$8(66.7 \%) \quad 4(33.3 \%)$

\section{GMPs Regarding Raw Materials, Product} Identification and Documentation Systems

All respondent slaughterhouses (100\%) showed clearly identified production date of products plus clear products code marks. Clearance of product details and finished product distribution records was revealed in ten farms $(83.3 \%)$. Regarding documentation systems, 91.7\% (n=11) was recorded for maintenance whereas it was only $50.0 \%(n=6)$ for calibration. Estimation of product color, leakage, and smell recorded $66.7 \%(n=8), 75.0 \%(n=9)$ and $58.3 \%(n=7)$ respectively (Table IV).

\section{E. Bacterial Analysis of Poultry Slaughterhouses' Halls and Meat Samples}

The results of bacterial growth are detailed in Table V and Fig. 1 For poultry slaughterhouses' samples, bacterial growth was shown in $60.0 \%(n=108)$ of all samples taken from different sites (surfaces, workers' hands, boots, water, and chillers) in the three localities. The distribution of bacterial growth per sample sites revealed that the most bacterial growth was detected in workers' hands which was $83.30 \%$ $(n=44)$, while water samples showed the least percentage of growth $(30.0 \%)$. The difference between growth state of bacteria in slaughterhouses' halls samples and sample sites 
was highly significant (P-value $=0.000$ and $\left.\chi^{2}=30.92\right)$.

TABLE IV: GOOD MANUFACTURING PRACTICES (GMPS) REGARDING RAW MATERIALS, PRODUCT IDENTIFICATION AND DOCUMENTATION SYSTEMS IN BROILER POULTRY SLAUGHTERHOUSES

\begin{tabular}{cc} 
SYSTEMS IN BROILER POULTRY SLAUGHTERHOUSES \\
\cline { 2 - 2 } Parameter & \multicolumn{2}{c}{ Yes } \\
\cline { 2 - 2 }
\end{tabular}

\section{Raw materials}

Incoming/outgoing raw

materials registration

A list of raw materials suppliers

Labeled and documented raw

materials

Product identification/Recall system

Product identification

Permanent, legible code marks

Date of production

identification

Documented products

estimation records

Packaging quality estimation

Clearance of product details

estimation

Color estimation

Smell estimation

Leakage estimation

Recall system

Documented written recall

procedure

Finished product distribution

records

Product complaint file

A recall coordinator

Documentation systems

Sanitation program

Calibration

Maintenance

Checks and audits

$\begin{array}{ll}8(66.7 \%) & 4(33.3 \%) \\ 11(91.7 \%) & 1(08.3 \%) \\ 10(83.3 \%) & 2(16.7 \%)\end{array}$

$12(100 \%)$

$0(00.0 \%)$

$12(100 \%)$

$0(00.0 \%)$

$11(91.7 \%) \quad 1(08.3 \%)$

$11(91.7 \%) \quad 1(08.3 \%)$

$10(83.3 \%) \quad 2(16.7 \%)$

$8(66.7 \%) \quad 4(33.3 \%)$

$7(58.3 \%) \quad 5(41.7 \%)$

$9(75.0 \%) \quad 3(25.0 \%)$

$7(58.3 \%) \quad 5(41.7 \%)$

$10(83.3 \%) \quad 2(16.7 \%)$

$5(41.7 \%) \quad 7(58.3 \%)$

$9(75.0 \%) \quad 3(25.0 \%)$

$9(75.0 \%) \quad 3(25.0 \%)$

$6(50.0 \%) \quad 6(50.0 \%)$

$11(91.7 \%) \quad 1(08.3 \%)$

$10(83.3 \%) \quad 2(16.7 \%)$

*The total number of respondent slaughterhouses was twelve.

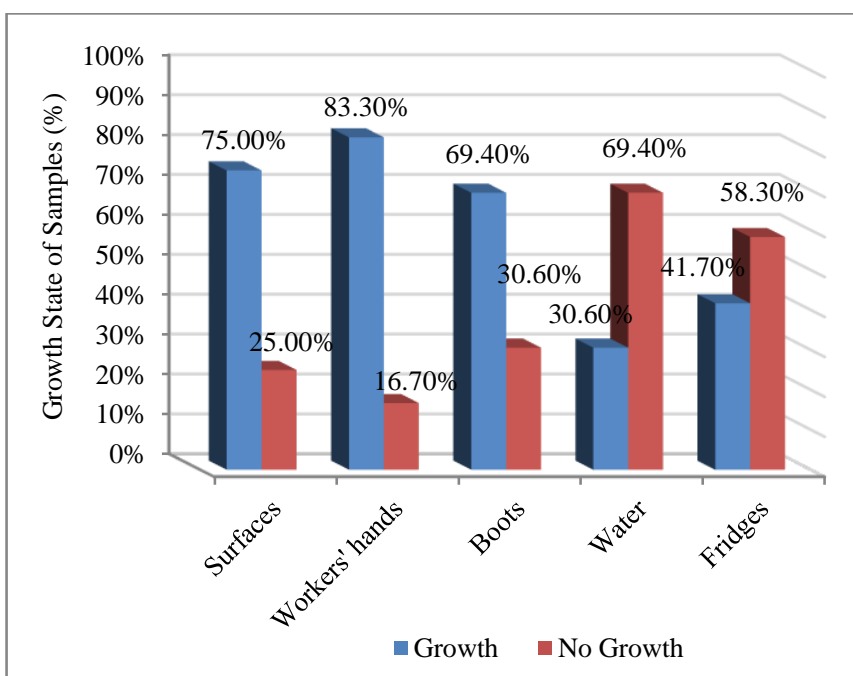

Fig. 1. Growth State of Bacteria in Slaughterhouses' Halls per Sample Site. $* \chi^{2}=30.92 \mathrm{df}=4.0 \mathrm{P}$-value $=0.000<0.01$ (Highly significant).

On the other hand, results of analysis of poultry meat swab samples revealed that $58.80 \%(n=141)$ of samples showed clear growth. Moreover, assessment of bacterial growth at different process steps showed that the majority of growth was detected after defeathering process which was $70.0 \%$ $(n=42)$. However, closely related bacterial growth percentages of $56.7 \% \quad(n=34)$ and $58.3 \% \quad(n=35)$ were observed after evisceration and chilling processes while the after washing process showed low percentage $(50.0 \%)$. There was no significant difference resulting from association of state of bacterial growth of poultry meat samples and different step processes in poultry slaughterhouses (Pvalue $=0.162$ and $\chi^{2}=5.14$ ) (Fig. 2).

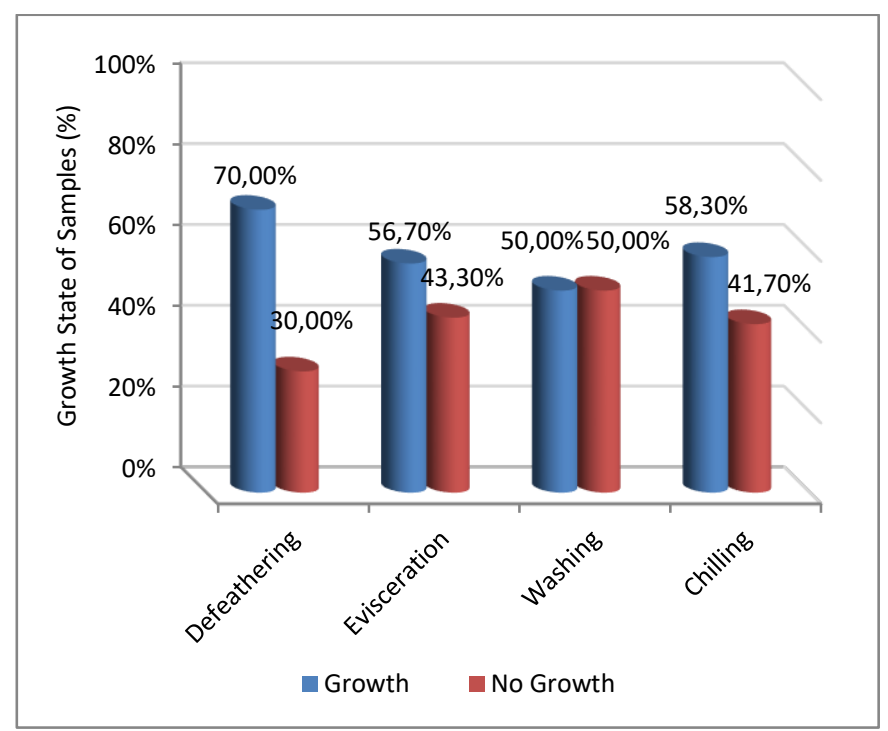

Fig. 2. Growth State of Meat Bacterial Samples per Process Steps. $* \chi^{2}=5.14 \mathrm{df}=3.0 \mathrm{P}$-value $=0.162>0.05$ (Not significant).

Bacterial classification of isolates in Gram stain revealed that the Gram-positive bacterial isolates presented the highest prevalence of $80.99 \%(n=230)$ while only $19.01 \%(n=54)$ were Gram negative bacteria (Fig. 3). Moreover, most Gram positive and Gram-negative isolates were detected in workers' hands at percentages of $19.60 \%(n=56)$ and $4.36 \%$ $(n=12)$, respectively while in process steps, most Grampositive bacteria were detected after defeathering which was $14.40 \%(n=41)$ and most of Gram negative were detected after evisceration $(2.49 \%)(n=7)$. The results are detailed in Fig. 4.

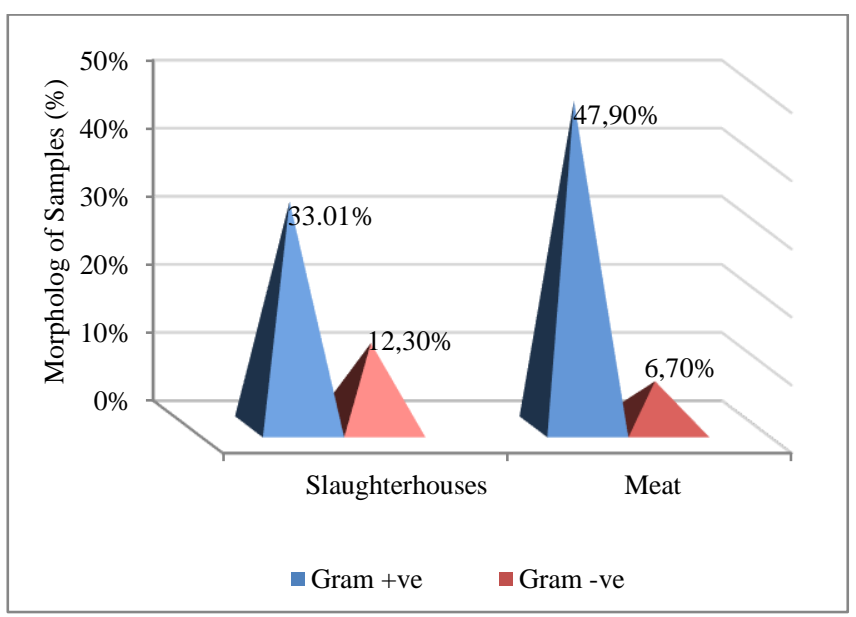

Fig. 3. Bacterial Morphology of Isolates of Slaughterhouses' Halls and Meat. Samples in Gram Stain.

A total of 284 isolates, out of 420 samples tested, had been characterized and identified. The mostly detected Gram positive species were Staphylococcus lentus $9.51 \%(\mathrm{n}=27)$, Staphylococcus aureus $7.75 \%(\mathrm{n}=22)$, Micrococcus vaians $5.63 \% \quad(\mathrm{n}=16), \quad$ Bacillus macerans $6.34 \% \quad(\mathrm{n}=18)$, Staphylococcus epidermides $7.04 \%(\mathrm{n}=20)$, and Micrococcus 
kristanae $8.45 \%(\mathrm{n}=24)$. For Gram-negative isolates, the most abundant Gram-negative species isolated were Escherichia coli $9.51 \% \quad(\mathrm{n}=27)$, Aeromonas spp. $2.82 \%$ $(\mathrm{n}=8)$, Citrobacter frundi $3.52 \% \quad(\mathrm{n}=4)$, Pseudomonas aeruginosa $3.52 \%(\mathrm{n}=10)$, Proteus mirabilis $0.70 \%(\mathrm{n}=2)$, and Salmonella spp. $1.41 \%(\mathrm{n}=4)$. The rest of the result is presented in Table V.

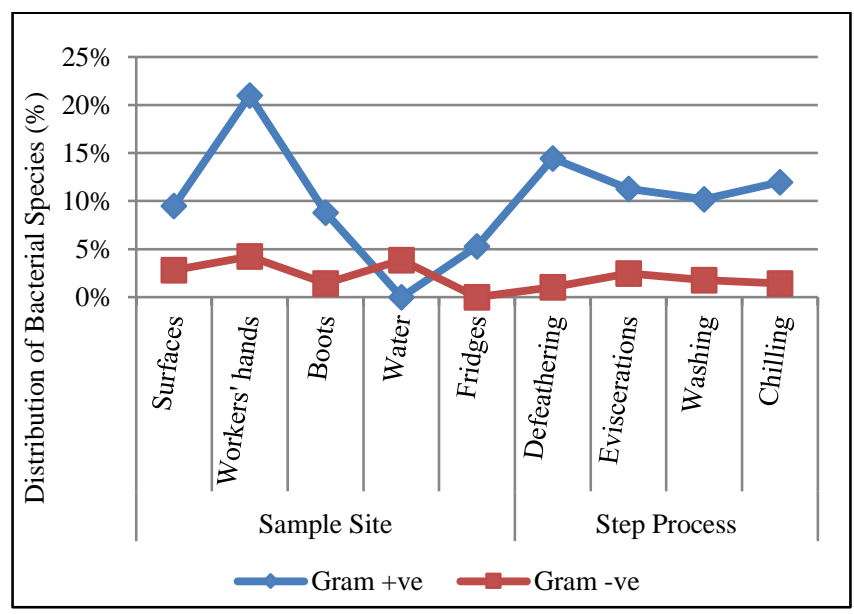

Fig. 4. Comparison of Distribution of Bacterial Species of Slaughterhouses Halls and Meat per Sample Sites and Process Steps in Khartoum State, Sudan.

TABLE V: IDENTITY OF BACTERIAL SPECIES ISOLATED OF SLAUGHTERHOUSES' HALLS AND MEAT SAMPLES IN KHARTOUM STATE, SUDAN

\begin{tabular}{ccc}
\hline & \multicolumn{2}{c}{ SUDAN } \\
\hline \multirow{2}{*}{ Species } & $\begin{array}{c}\text { Slaughterhouses } \\
\text { Halls }\end{array}$ & Total \\
\cline { 2 - 2 } & Frequency $(\%)$ & \\
\hline
\end{tabular}

Gram +ve species

Micrococcus lentus

Staphylococcus aureus

Micrococcus vaians

Bacillus macerans

Staphylococcus

epidermides

Micrococcus kristanae

Bacillus cereus

Staphylococcus hyicus

Staphylococcus lentus

Micrococcus roseus

Aerococci spp.

Staphylococcus xylosus

Staphylococcus hominis

Micrococcus luteus

Micrococcus lylae

Staphylococcus roseus

Kurthia spp.

Staphylococcus kloosis

Listeria spp.

Sub total

Gram -ve species

Escherichia coli

Aeromonas

Pseudomonas

aeruginosa

Citrobacter freundii

Proteus merabilis

Salmonella spp.

Sub total

Total

$\begin{array}{cc}17(5.99 \%) & 10(3.52 \%) \\ 11(3.87 \%) & 11(3.87 \%) \\ 10(3.52 \%) & 6(2.11 \%) \\ 9(3.17 \%) & 9(3.17 \%) \\ 8(2.82 \%) & 12(4.23 \%) \\ 7(2.46 \%) & 17(5.99 \%) \\ 6(2.11 \%) & 7(2.46 \%) \\ 6(2.11 \%) & 3(1.06 \%) \\ 5(1.76 \%) & 7(2.46 \%) \\ 4(1.41 \%) & 5(1.76 \%) \\ 4(1.41 \%) & 6(2.11 \%) \\ 3(1.06 \%) & 6(2.11 \%) \\ 2(0.70 \%) & 3(1.06 \%) \\ 1(0.35 \%) & 5(1.76 \%) \\ 1(0.35 \%) & 2(0.70 \%) \\ 0(0.00 \%) & 1(0.35 \%) \\ 0(0.00 \%) & 13(4.58 \%) \\ 0(0.00 \%) & 1(0.35 \%) \\ 0(0.00 \%) & 1(0.35 \%) \\ 94(33.01 \%) & 136(47.89 \%) \\ \end{array}$

$16(5.63 \%) \quad 11(3.87 \%)$

$8(2.82 \%) \quad 0(0.00 \%)$

$7(2.46 \%) \quad 3(1.06 \%)$

$3(1.06 \%) \quad 1(0.35 \%)$

$1(0.35 \%) \quad 1(0.35 \%)$

$0(0.00 \%) \quad 4(1.41 \%)$

$35(12.32 \%) \quad 19(6.69 \%)$

$129(45.42 \%) \quad 155(54.57 \%)$
$27(9.51 \%)$

$22(7.75 \%)$

$16(5.63 \%)$

$18(6.34 \%)$

$20(7.04 \%)$

$24(8.45 \%)$

$13(4.58 \%)$

$9(3.17 \%)$

$12(4.23 \%)$

$9(3.17 \%)$

$10(3.52 \%)$ regulations and the HACCP rules. The study revealed that

$9(3.17 \%)$ most of the respondents were aware of the food hygiene

$5(1.76 \%)$

$6(2.11 \%)$

$3(1.06 \%)$

$1(0.35 \%)$ poultry slaughterhouses studied did not apply developed

$13(4.58 \%)$ personal hygiene procedures, poultry meat product hygiene

$1(0.35 \%)$ practices, and proper cleaning and disinfection procedures

$1(0.35 \%)$ and all these poultry slaughterhouses had no GMPs except

$230(80.99 \%)$ one company that had developed TQM program but all

$27(9.51 \%)$ poultry slaughterhouses examined did not implement $8(2.82 \%)$ HACCP plan. Furthermore, lack of sanitary facilities $10(3.52 \%)$ including dispensers, personnel changing rooms, toilet facilities and washing basins added to the inadequacies.

$4(1.41 \%) \quad$ Although water used in processing was potable and both cold $2(0.70 \%)$ and hot water supply were also provided, microbiological $54(19.01 \%)$ testing of water was only practiced in half of the premises. $284(100 \%)$ The above findings are in agreement with Paster [31] who considered documented staff training program and preventative maintenance program, training and qualification for responsibilities, appropriate use of personal facilities by the staff, and sanitary facility as essential prerequisites to 
manage cross-contamination and prevent microbial growth. Adequate refrigeration, supply of electricity with extra electric power supply for emergency cut were observed in most of the examined slaughterhouses in the presented study and this may be attributed to the fact that the producers were aware of unstable electric supply in Sudan which may lead to spoilage of poultry meat due to contaminants growth in temperature below the optimum.

Although clearly detailed and documented finished product for maintenance and distribution records were shown in most of slaughterhouses studied, moderate estimation regarding final product color, leakage, and smell was recorded. These observations were not in consistent with Codex advice on the importance of monitoring and documentation procedures as a prerequisite step in a HACCP plan for meat and meat products [27]. Barnett et al. [32] stated that keeping and meeting production targets are good management practices that allow the identification and solution of problems. Identifying the cause of and fixing a problem is an important part of personnel knowledge base and can assist in preventing a recurrence of the problem. Records kept over time can help identify some of the possible causes of problems in poultry slaughterhouses. One of the most useful record-keeping documents is a diary, which can be used in combination with record-keeping sheets to record major activities, problems identified, equipment repairs, deviations from equipment settings, and any staff issues.

Inconsistent with Kaferstein [33] that workers in food premises were the major sources of contamination either as carriers of pathogens or through poor personal hygienic practices, the current study detected most bacterial growth in workers' hands in poultry slaughterhouses and this can be due to unhealthy worker's practices and habits observed in majority of them during work such as not washing hands before entering production areas, smoking, and eating and drinking in processing areas specially that only few of them were restricted to annual medical check to prove fitness to work and not well trained or accustomed to appropriate protective wearing. The same findings were also estimated and expressed as agreed by [34] in their study to identify perception, awareness and knowledge on food safety and quality assurance related to poultry slaughterhouses in Indonesia. Another study [35], [36] revealed that the workers' hands and the equipment were the main sources of meat contamination which are in accordance with the present results. The previous findings ascertained that the reduction or elimination of contamination sources is directly related to practicing good sanitary measures and application of appropriate methods during slaughtering operations, using adequate water and disinfection.

Bacterial analysis of meat samples revealed clear growth in more than half of the tested samples with high significant difference in association between state of growth of meat samples and slaughterhouses' site. In reference to assessment of bacterial growth at different step processes (SPs), the majority of growth was detected after defeathering process and this is in agreement with Göksoy et al. [37] and Gabeer [10] who concluded that broilers arriving to the poultry slaughter house for processing are generally highly contaminated with potential human pathogenic bacteria such as Salmonella spp.. Moreover, a study in Sudan by [38] to investigate the contaminating micro-organisms during poultry meat processing found that the bacterial growth obtained from chicken carcasses after washing and after chilling were lower than those reported in other SPs. However, closely related bacterial growth percentages were observed after evisceration and chilling processes while the after washing process showed the least percentage. Isolation of bacterial species from poultry carcass samples revealed that the mostly detected Gram positive species were Micrococcus lentus, Staphylococcus aureus, Micrococcus vaians, Bacillus macerans, and Staphylococcus epidermides and Micrococcus kristanae. For Gram negative isolates, the most abundant Gram negative species isolated were Escherichia coli, Aeromonas spp., Citrobacter frundi, Pseudomonas aeruginosa, Proteus mirabilis, and Salmonella spp. Type and level of contaminant bacteria isolated from poultry meat in different slaughterhouses was studied by different researchers. Relevant to our study, Abdalla et al. [38] studied microbial contamination of broilers in modern abattoirs in Khartoum State in 9 process steps. The bacteria species isolated from different PSs were Staphylococcus aureus, Staphylococcus albus, Escherichia coli and Salmonella. spp. Their results showed variability of microbial counts during processing of broilers carcasses that may cause public hazards. Similar study by Munir, et al. [39] investigated the bacterial contaminants of poultry meat in Khartoum State to estimate the level of meat safety for human consumption. Their study showed that Escherichia coli represented the highest contaminant followed by Proteus spp. then Citrobacter spp. and Salmonella spp. Similar findings were obtained by Ahmed [40] and Mohamed [41] who stated that chicken faecal contamination was behind the cause of the large numbers of isolates of Escherichi. coli they recovered. The isolation of bacteria from workers' hands in this study, and the presence of Escherichi. coli can be attributed to carcass contaminated with the gastrointestinal contents during processing. The occurrence of Staphylococcus aureus as shown in the current study is alarming and represents a relevant issue with regard to food safety that should be considered specially that this bacterium was isolated from workers' hands and with meat contaminants which ascertains the possibility of contamination of meat through human handling and processing making poultry and poultry products important vehicles for transmission. Consistent to our above findings, [42], [43] have shown that Staphylococcus aureus is one of the leading microorganisms associated with food poisoning that is mostly recognized on the skin, mucous membranes of humans and animals, and also as an environmental contaminant thus causing human outbreaks. A general review on food safety system with reference to meat operations in Khartoum State, Sudan was represented by [20]. They reported that the situation of microbial contamination in poultry meat in Khartoum State abattoirs was higher than the levels recommended by international regulatory bodies. The review pointed out the strengths and weaknesses of the Sudanese Meat Safety Management System with regard to HACCP system concluding that, the current condition and level of applicability of the HACCP prerequisites programs was still below the recommended level.

We concluded that adoption of HACCP system and HACCP PRPs as a food safety control has not been given 
serious attention among owners, managers, and workers in most of the studied large broiler production companies indicating lack of knowledge and resources beside absence of role of official authorities. Bacterial contamination found in slaughterhouses' halls samples specially from workers' hands contribute significantly to contamination of broiler carcasses since both slaughterhouses' halls samples and meat samples in different slaughtering PSs were found contaminated with harmful pathogenic bacteria.

It is recommended that formulation of suitable procedures for implementing HACCP PRPs by specialized authorities are needed to improve the level of hygienic broiler production. The PRPs provide the foundation for effective HACCP implementation and should be in place before any HACCP-based procedures are established. Thus, HACCP is not a stand-alone programme and should be supported by PRPs (GHP and GMP). Enforcement of HACCP PRPs in broiler premises should be taken as one unit including the slaughtering practice and behavior, required slaughterhouse reformation, owners and workers knowledge, economic benefit, and infrastructure with proper equipments to ensure ideal implementation and optimum standards of food safety to assure safety of poultry meat from "farm to table".

\section{REFERENCES}

[1] Mohamed M. Sirdar. The Sudanese History Statistics and Future Investment Challenges. MSc, Thesis, University of Pretoria, 2014.

[2] Sirdar M. M., Picard J., Bisschop S., Jambalang A. R., Gummow B. "A Survey of Antimicrobial Residues in Table Eggs in Khartoum State, Sudan, 2007-2008," Onderstepoort Journal of Veterinary Research, vol.79, no. 1, pp. 360-369, 2012.

[3] Elghouth F. O., Yassin O. E., Angara T. E., Wahab A., "Some Management and Economic Aspects of Broiler Production in Khartoum State," Journal of Agricultural and Veterinary Sciences, vol. 1, no. 14, pp. 80-85, 2013.

[4] Daghir, N. J. Poultry Production on Hot Climates, 2nd ed. CAB Internatinal Wallingford, Oxford Shire, U.K, 2008.

[5] Mahmoud M. A., Abdelgadir A. E., Hayfa M. I., "Evaluation of Biosecurity Measures on Broiler farms in Khartoum, Sudan," Journal of Veterinary Medicine and Animal Health, vol.6, no. 5, pp. 138-144, 2014.

[6] Agricultural census - 2008, Ministry of Agriculture, Animal Resources and Irrigation, Khartoum State, Sudan, 2009.

[7] Mead G. C., "Safety of Poultry Products Past, Present and Future," Meat and Poultry News, 1997, 8(7): 26-27.

[8] Mormile M. R., Oakley B. B., Morales C. A., Line J., Berrang M.E., Meinersmann R. J., Tillman G. E., Wise M. G., Siragusa G. R., Hiett K. L., Seal B. S., The Poultry-Associated Microbiome: Network Analysis and Farm-to-Fork Characterizations, PLOS ONE, ;8:e57190, 2013.

[9] Zhao C., Ge B., De Villena J., Sudler R., Yeh E., Zhao S., Meng J, "Prevalence of Campylobacter spp., Escherichia coli, and Salmonella Serovars in Retail Chicken, Turkey, Pork, and Beef from the Greater Washington, D.C., Area," Appl Environ. Microbiol., vol. 67, no. 5, pp. 5431-5436, 2001.

[10] Gabeer G. A. K., Suliman S. E. Ghali A., Abdalla M. A. "Microbial Contamination of Chicken Carcasses During Slaughtering Process in Khartoum State, Sudan," Assiut Vet. Med. J., vol. 58, pp. 134-139, 2012.

[11] Mead, G. C., "Microbiological Quality of Poultry Meat: A Review," Brazilian Journal of Poultry Science, vol. 6, no. 3, pp.135-142, 2004.

[12] Rouger A., Tresse O., Zagorec M, "Bacterial Contaminants of Poultry Meat: Sources, Species, and Dynamics," Microorganisms, vol. 5, no. 50, pp. 1-16, 2017.

[13] Sharma B., "Poultry Production, Management and Bio-Security Measures," Journal of Agriculture and Environment, vol. 11, no. 1, pp. 122-125, 2010.

[14] "Food Safety Risk Analysis: A Guide for National Food Safety Authorities," WHO, 2006.
[15] Sulieman M.F., "Egg Characteristics, Genetic and Phenotypic Relationships of Body Weight at Various Ages in Indigenous Chickens," Master Thesis, University of Khartoum, 1996.

[16] Jensen H. A., "Paradigm and Visions: Network for Poultry Production in Developing Countries,". In: F Dolberg and P H Petersen (eds.) Poultry as a Tool in Poverty Eradication and Promotion of Gender Equality Proceedings of a workshop, March 22-26, 1999, Tune Landboskole, $\quad$ Denmark. $2000 . \quad$ Available: http://www.fao.org/3/ac154e/AC154E02.htm.

[17] WHO (2000). Food Safety: Resolution of the Executive Board of the WHO, 105th Session. Available: http://apps.who.int/gb/archive/pdf_files/EB105/ee10.pdf.

[18] Ahmed H. A., "Bacterial Contamination of Chicken Carcasses at Abattoir in Khartoum State, Sudan.” A dissertation Submitted to Sudan University of Science and Technology, 2014.

[19] Abdalla A., Suliman S., Shuaib Y., Abdalla M, "Bacteriological Study of Poultry Meat in Semi-Automatic Abattoir in Khartoum State," Journal of Agricultural and Veterinary Sciences, vol. 14, no. 2, pp. 80$85,2013$.

[20] Elniema A., Mustafa, Adil M. A., Salman, Iman, M. Hamad, "Review on Food Safety System with Reference to Meat Operations in Khartoum State, Sudan," RA Journal of Applied Research, vol. 2, no. 7, pp. 491-504, 2016.

[21] Domenech E., Escriche I., Martorell S., "Assessing the Effectiveness of Critical Control Points to Guarantee Food Safety," Food Control, vol. 19, no. 6, pp. 557-565, 2008.

[22] Youssif A., "Applicability of Hazard Analysis and Critical Control Points (HACCP) System in Beef Processing Factories in Khartoum State," EC Microbiology, vol. 1, no. 2, pp. 70-87, 2015.

[23] Wagge Alla, H. A., "Dimensions and Impact of Application of Extension, Laws, and Regulations, Applied Research and Quality Control on Poultry Industry in Khartoum State," Ph.D. Thesis, Sudan Academy for Sciences, Khartoum, Sudan, 2011.

[24] Thrusfield M. Veterinary Epidemiology. 3rd Edition, Blackwell Science Ltd., Oxford. UK. John Wiley and Sons, 2007.

[25] Cowan S. T., Steel K. J., Barrow G. I., Feltham R. K. A. Cowan and Steel's Manual for the Identification of Medical Bacteria, New York: Cambridge University Press, 1993.

[26] Levesque R., SPSS Programming and Data Management: A Guide for SPSS and SAS Users (4th ed.). Chicago, Illinois: SPSS Inc. ISBN 9781-56827-390-7, 2007.

[27] CAC (Codex Alimentarius Commission). HACCP Code of Hygiene $\begin{array}{lll}\text { Practice for } & \text { Meat. Available: }\end{array}$ file://C:/Users/acer/Desktop/CXP_058e.pdf.

[28] Abdalla M. A., Suleiman S. E., Alien Y. Y. H. A., Bakheit O, "Food Safety Knowledge and Practices of Street Food-vendors in Khartoum City," Sudan J. Vet. Sci. Anim. Husb, vol. 47, pp. 126-136, 2008.

[29] Fielding L. M., Ellis L., Dr Beveridge C., Peters A. C., “An Evaluation of HACCP Implementation Status in UK Small and Medium Enterprises in Food Manufacturing," International Journal of Environmental Health Research, vol. 15, no. 2, pp. 117-126, 2005.

[30] Nasr N. B. A. "Assessment of Food Safety Knowledge, Attitude and Practices among Poultry Slaughterhouses Plant Workers in Khartoum State, Sudan," Ph.D. Thesis, Sudan University of Science and Technology, 2013.

[31] Paster T. "The HACCP Food Safety Training Manual.," Hoboken, N. J., Chichester, John Wiley, 2006.

[32] Barnett J. L., Glatz P. C., Almond A., Hemsworth P. H., Cransberg P. H., Parkinson G. B., Jongman, E. C., "A Welfare Audit for the Chicken Meat Industry: Supporting Documentation for the Egg Industry's National Quality Assurance." Rural Industries Research and Development Corporation, Canberra, Australia. 2001. Available: http://www.fao.org/3/a-al738e.pdf.

[33] Kaferstein F. K., "Food Safety: The Fourth Pillar in the Strategy to Prevent Infant Diarrhea," Bulletin of the WHO, vol. 81, no. 11, pp. 842843, 2003.

[34] Phumkrachai B., Vasasiri H., Samart P., Kongboonkeaw F., Unger F., Artama W., Widiasih D. A., Pichpol D., Meeyam T., Hygienic Practices, Knowledge and Perception on Food Safety and Quality Assurance Systems in Poultry Slaughterhouses and Slaughter Poultry Market in Yogyakarta, Indonesia. 2013. Available: http://vphcap.vet.cmu.ac.th/Symposium/download/VPHCAP.pdf.

[35] Jeffery B., Donald A. B., Gill C. O, "Implementation of Validated HACCP System for the Control of Microbiological Contamination of Pig Carcass at a Small Abattoir," Canadian Vetetranry Journal, vol. 44 , no. 1 , pp. 51-55, 2003.

[36] Ali A. A., "Prevalence of Bacterial Contamination of Public Health Concern on Bovine Carcasses at Khartoum State, Sudan." Master Thesis, Sudan University of Science and Technology, 2007. 
[37] Göksoy E. Ö., Kirkan S., Kök F, "Microbiological Quality of Broiler Carcasses During Processing in Two Slaughterhouses in Turkey." Poultry Science, vol. 83, no. 8, pp. 1427-1432, 2004.

[38] Abdalla M., Mohamed-Noor S. E., Shuaib Y., Suliman S. E, "Study of Microbial Contamination of Broilers in Modern Abattoirs in Khartoum State." The Annals of the University Dunarea de Jos of Galati Fascicle VI-Food Technology, vol. 36, pp. 74-80, 2012.

[39] Munir E. H., Khalifa K. A., Mohammed A. M., "Status of Food Safety Due to Bacterial Contaminants of Poultry Meat and Poultry Products in Khartoum State," Journal of Scientific Research and Reports, vol. 3, no. 14, pp. 1897-1904, 2014.

[40] Ahmed K. K., "Meat Hygiene Assessment in a Slaughter House in Khartoum State." Master Thesis, University of Khartoum, 2004.

[41] Mohammed A. M., Implementation of Hazard Analysis Critical Control Point (HACCP) System in a Poultry Processing Plant. Master Thesis, University of Khartoum, 2000.

[42] Altabari G. and Al-Dughaym A. M., "The Role of Sanitary Inspection of Meat in Relation of Food Poisoning," Proceedings of the 2nd Annual Scientific Meeting for Environment Hygiene, (Meat Hygiene), Riyadh, Saudi Arabia, pp. 180-203, 2002.

[43] Feizi A. M., Nazeri A., Pilevar, "Isolation of Staphylococcus spp. Genera from Broiler Breeder Flocks in East Azerbaijan Province of Iran: Prevalence and Antimicrobial Susceptibility," Afr. J. Microbiol. Res., vol. 6, no. 28, pp. 5819-5823, 2012. 